\title{
EDUCAÇÃO AMBIENTAL NA FORMAÇÃO INICIAL DE PROFESSORES DE CIÊNCIAS: UM OLHAR NAS ATAS DO ENPEC
}

\author{
ENVIRONMENTAL EDUCATION IN THE INITIAL FORMATION OF \\ SCIENCIA TEACHERS: A LOOK IN THE ENPEC MINUTES
}

\begin{abstract}
Rafaela Engers Günzel ${ }^{1}$
Aline Machado Dorneles ${ }^{2}$

Resumo: As Diretrizes Curriculares Nacionais da Educação Básica (DCNEB) instituem com base na Lei n 9.795/1999, a obrigatoriedade da Educação Ambiental em todos os níveis educacionais. Diante desse pressuposto, buscamos neste estudo realizar uma revisão nas atas do Encontro Nacional de Pesquisa em Educação em Ciências (ENPEC) com objetivo de compreender como se apresenta a temática da Educação Ambiental na formação inicial de professores. A análise dos trabalhos do ENPEC foi realizada pelo viés da Análise Textual Discursiva (ATD). Um conjunto de 18 artigos constitui a proposta de análise, seguido do processo de unitarização e categorização, ao qual emergiu três categorias finais. Enfim, reforçamos para a potencialidade da temática em investigação, com destaque para a interdisciplinaridade, considerando os aspectos emergentes nos metatextos construídos com base nas pesquisas compartilhadas em um dos maiores eventos da área de Ciências.
\end{abstract}

Palavras-chave: Ambientalização; Educação Superior; Interdisciplinaridade.

Abstract: The National Curriculum Guidelines for Basic Education (DCNED) are established based on Low No 9.795/1999, the obligation of Environmental Education at all educational levels. Facing this assumptions, we sought the aim of this study is to review the minutes of the National Meeting of Research in Science Education (ENPEC) in order to understand how the theme Environmental Education in initial teacher training is presented. The analysis was performed by the bias of Discursive Textual Analysis (ATD). A set of 18 articles constitute the proposed analysis, followed by the process of unitarization and categorization, which emerged three final categories. Finally, we reinforce the potentiality of the research theme, especially interdisciplinarity, considering the emerging aspects in metatext based on shared research in one of the largest events in the area of science.

Keywords: Environmentalization; College Education; Interdisciplinarity.

\section{Considerações iniciais}

As discussões sobre as questões ambientais no Brasil estão sempre vigentes, e os ataques recentes como vividos no ano de 2019 - como o favorecimento do desenvolvimento econômico de empreendimentos como o agronegócio e a mineração, e

\footnotetext{
${ }^{1}$ Mestranda em Educação em Ciências, Universidade Federal do Rio Grande (FURG). Universidade Federal do Rio Grande (FURG), Rio Grande, Rio Grande do Sul, Brasil. E-mail: rafaela.gunzel@gmail.com

${ }^{2}$ Doutora em Educação em Ciências, Universidade Federal do Rio Grande (FURG). Universidade Federal do Rio Grande (FURG), Professora Adjunta da Escola de Química e Alimentos da FURG, Rio Grande, Rio Grande do Sul, Brasil. E-mail: lidorneles26@gmail.com
} 
DOI: https://doi.org/10.33238/ReBECEM.2020.v.4.n.2.24146

também, a desvalorização de importantes instituições ${ }^{3}$ como o IBGE, INPE, FIOCRUZ, IMCBio e outras, colocam sob ameaça a trajetória da Educação Ambiental (EA) brasileira. Desse modo, faz-se necessário assegurar as Políticas Públicas de EA, fomentando o seu debate no âmbito formal de ensino, como nos processos de formação inicial e continuada de professores.

As questões ambientais, por inúmeros motivos, perpassam as instituições de ensino como sendo uma temática indispensável. Entre tantos movimentos possíveis para a área educacional, a EA configura-se como uma proposta transversal e interdisciplinar, com diversos níveis de complexidade e possibilidades. Por essas razões, concordamos com Loureiro (2003) quando nos convida a promover o diálogo, como um princípio indissociável para a democratização dos conflitos ambientais instituídos na sociedade, configurando-se o diálogo como imprescindível para compreender a importância da temática ambiental, principalmente, se pensarmos sobre o que Brandão (2005, p. 52) expõe:

Vivemos sempre uma vida plural, coletiva e solidária. Aprendemos ao longo de muitos milhares de anos a nos fazermos seres humanos, porque bem ou mal aprendemos a conviver. Aprendemos uns com os outros a vivermos juntos, a partilhar entre nós uma vida que, sem esses exercícios de partilha em comum, seria impossível.

No contexto diário, estabelecemos relações sociais com os outros e com o ambiente, o tempo todo, assim, os problemas ambientais precisam ser discutidos, pois a sustentabilidade ainda é um desafio de alcance utópico e precisa ser almejada de modo coletivo, com a discussão da EA nas instituições de ensino. Souza (2011, p. 43) sustenta a ideia de Rodas de Formação como uma proposta para os professores, e estabelece que “[...] a aposta é na interdisciplinaridade enquanto emergência e não como condição previamente determinada para articulações na escola".

Com a EA em pauta, temos a necessidade de investir na formação de professores, para que estes estejam aptos a lidar com as questões emergentes dessa temática, pois as Diretrizes Curriculares Nacionais da Educação Básica (DCNEB) no ano de 2013 estabeleceram uma proposta e instituíram no mesmo documento as Diretrizes Curriculares Nacionais para a Educação Ambiental (DCNEA). O documento tem como objetivo a implementação da EA tendo como referência as Diretrizes Curriculares Nacionais Gerais da Educação Básica e as Diretrizes Curriculares Nacionais para as

\footnotetext{
${ }^{3}$ Instituto Brasileiro de Geografia e Estatística (IBGE). Instituto Nacional de Pesquisas Espaciais (INPE). Fundação Oswaldo Cruz (FIOCRUZ). Instituto Chico Mendes de Conservação da Biodiversidade (IMCBio).
} 


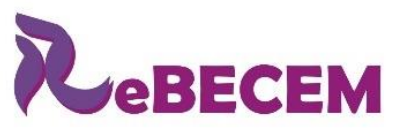

Revista Brasileira de Educação em

Ciências e Educação Matemática

DOI: https://doi.org/10.33238/ReBECEM.2020.v.4.n.2.24146

Graduações, em especial as de Formação de Professores. Objetiva ainda, sistematizar

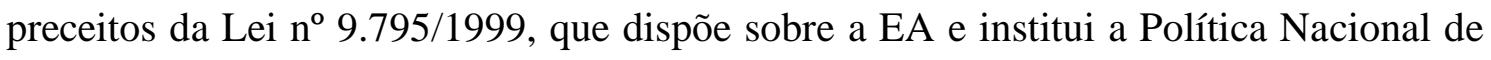
Educação Ambiental (PNEA), além de, orientar os cursos de formação de docentes para a Educação Básica, e todos os sistemas e redes educativas a incluir a EA nos currículos, nos projetos institucionais e pedagógicos das instituições de ensino (MEC, 2013).

As leis e diretrizes nacionais servem de parâmetro para uma base nacional, e apontam como sendo fundamental que a EA seja incorporada aos currículos e trabalhada no contexto educacional. Porém, muito além de estar documentada, a EA precisa estar presente nos espaços educacionais como temática transversal e interdisciplinar de formação como apontada nas Diretrizes, buscando uma educação emancipatória e crítica. Portanto, queremos buscar nesta pesquisa, compreender como se apresenta a EA na formação inicial de professores de Ciências.

É necessário que a EA esteja imersa nos currículos da Educação Superior, no processo formativo inicial de professores, visando à constituição de profissionais que promovam espaços de debate e a construção de posicionamentos relacionados à EA. A licenciatura (como também outras graduações) é um lugar privilegiado para a formação de educadores ambientais, constituídos como sujeitos políticos engajados em mudar a realidade em que atuam/atuarão incorporando a dinâmica da sustentabilidade (DICKMANN, 2017). Sobre a formação inicial de professores, as DCNEB (MEC, 2013) mencionam o que a Lei $n^{\circ}$ 9.795/1999 preceitua em seu artigo 11, que “[...] a dimensão ambiental deve constar nos currículos de formação de professores, em todos os níveis e em todas as disciplinas". A referida Lei estabelece também no artigo 2 que a EA “[...] é um componente essencial e permanente da educação nacional, devendo estar presente, de forma articulada, em todos os níveis e modalidades do processo educativo, em caráter formal e não-formal".

Junto de Dickmann (2017, p. 66) defendemos que a EA não deve constituir uma disciplina específica, pois não acreditamos "[...] que a melhor maneira de trabalhar as questões socioambientais na escola seja via uma disciplina. Se isso fosse verdade nossos estudantes seriam brilhantes em Português e Matemática, o que não ocorre”. E ainda, “[...] uma disciplina converge para uma visão cartesiana de Educação Ambiental, remetendo para o engavetamento do conhecimento e reforça o modelo atual de educação e escola - que tanto criticamos". É preciso, portanto, criar processos que viabilizem o envolvimento do coletivo de professores, principalmente durante sua formação inicial, na busca de atender os princípios e objetivos do PNEA. No atual momento educacional, 


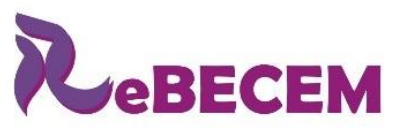

Revista Brasileira de Educação em

Ciências e Educação Matemática

DOI: https://doi.org/10.33238/ReBECEM.2020.v.4.n.2.24146

temos um novo documento de caráter normativo aprovado pelo Governo para a Educação Básica: a Base Nacional Comum Curricular (BNCC). Essa nova base também traz implicações para a formação de professores e para o trabalho com a EA. Em uma pesquisa realizada sobre a EA na BNCC da Educação Infantil e Ensino Fundamental, Behrend, Cousin e Galiazzi (2018) encontram referência à temática somente no Ensino Fundamental, estando limitada às Ciências da Natureza e Geografia. As pesquisadoras apontam que, dentre as palavras-chaves utilizadas no documento, EA aparece uma única vez na introdução e é “[...] apresentada como mais um dos temas contemporâneos que devem ser incorporados aos currículos e às propostas pedagógicas das escolas, preferencialmente de forma transversal e integradora" (p. 81).

A EA pode ser considerada, entre tantas outras definições e necessidades, uma inovação educativa "[...] que questiona o que é qualidade de vida, reflete sobre a ética ecológica e amplia o conceito de ambiente" (LOUREIRO, 2003, p. 37). Para tanto, com o exposto até o presente momento, buscamos nesta pesquisa apresentar algumas compreensões, com o seguinte questionamento: Como se mostra a EA na formação inicial de professores nas diferentes linhas temáticas dos anais do ENPEC? Com a pesquisa, buscamos respostas para a questão exposta, para isso, apresentamos a seguir detalhadamente o caminho metodológico, e os resultados e discussões sobre o desenvolvimento do processo de análise. Na sequência, os metatextos construídos para as categorias emergentes e seus argumentos aglutinadores, que reforçam as considerações gerais e finais da pesquisa aqui apresentada.

\section{Caminho metodológico da pesquisa}

Para constituição do corpus de análise, utilizamos nesta pesquisa os princípios metodológicos da Análise Textual e Discursiva (ATD) proposta por Moraes e Galiazzi (2016). Iniciamos, a partir das inquietações da pesquisa, com o levantamento de dados detalhado nos anais do ENPEC, em todas as onze edições publicadas ${ }^{4}$ (1997 até 2017). Para compor o corpus, coletamos somente os artigos completos disponíveis. No primeiro filtro, utilizamos o descritor “ambient”, considerando as variações possíveis (exemplos: ambiente(s), ambientalização, socioambiental, ambiental, CTSA), centralizamos a busca para o título de todos os trabalhos do evento, mesmo nas edições em que constavam

${ }^{4} \mathrm{O}$ levantamento inicial de dados desta pesquisa foi apresentado na XII edição do evento, ocorrido em junho de 2019 em Natal - RN. 
DOI: https://doi.org/10.33238/ReBECEM.2020.v.4.n.2.24146

separados por áreas temáticas. Esse filtro resultou em 451 artigos, sendo que o evento possuí mais de 6 mil trabalhos publicados.

Dos 451 trabalhos filtrados utilizando o descritor, realizamos um segundo filtro, agora promovendo a leitura do título, resumo e palavras-chave, com a intenção de selecionar os que se referiam à Formação Inicial de Professores. Assim, chegamos em 18 artigos, que constituem nosso corpus de análise. Na Tabela 1, apresentamos os trabalhos encontrados em cada um dos filtros, de acordo com a edição da qual pertencem. Podemos observar um crescente aumento de trabalhos sobre EA, que pode ter-se dado devido a diversos fatores, como ampliação dos pesquisadores da área de Ensino de Ciências e aumento de pesquisas sobre o tema.

Tabela 1: Resultados dos trabalhos do ENPEC por edição com os descritores

\begin{tabular}{ccccccccccccc}
\hline Edição & I & II & III & IV & V & VI & VII & VIII & IX & X & XI & Total \\
"ambient" & 0 & 0 & 6 & 12 & 46 & 48 & 63 & 93 & 62 & 59 & 96 & $\mathbf{4 5 1}$ \\
Formação Inicial & 0 & 0 & 0 & 0 & 0 & 1 & 1 & 5 & 4 & 3 & 4 & $\mathbf{1 8}$ \\
\hline
\end{tabular}

Fonte: Elaborado pelas autoras, 2019

Encontramos trabalhos relativos à temática em estudo nesta pesquisa somente nas últimas 6 edições do evento. O baixo número de trabalhos encontrados fortalece nossa intenção de investigação, uma vez que precisamos explorar o tema da EA relacionado à formação inicial de professores. Dessa forma, iniciamos a etapa de unitarização da ATD, com a leitura atenta dos 18 artigos, e a fragmentação dos textos, que Moraes e Galiazzi (2016) chamam de Unidades de Significados (US). Essas US buscam responder à pergunta de pesquisa e fazem parte do movimento de desordem proposto pela metodologia. Chegamos em 87 US, e com a intenção de passar para a etapa de autoorganização, elaboramos palavras-chave e título para cada US, visando facilitar o processo de categorização inicial. No movimento de categorização (inicial, intermediária e final), a proposta de Moraes e Galiazzi (2016) é agrupar as US que contenham elementos semelhantes. Nesse processo, agrupamos inicialmente nossas US em 14 categorias que convergiram em 3 categorias finais emergentes.

Tabela 2: Categorias Finais emergentes da etapa de categorização

\begin{tabular}{cc}
\hline Categoria Final & $\mathbf{N}^{\mathbf{0}}$ de US \\
\hline Formação ambiental docente na perspectiva de uma educação crítica & 43 \\
Ambientalização curricular para a formação inicial de professores & 38 \\
Estratégias didáticas para temas ambientais na formação docente & 26 \\
\hline
\end{tabular}

Fonte: Elaborado pelas autoras, 2019

Algumas US podem estar presentes em mais de uma categoria, dependendo das semelhanças. Para cada uma das três categorias finais, construímos um metatexto, que 


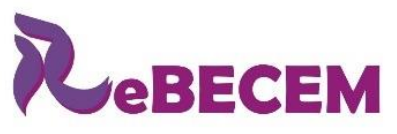

Revista Brasileira de Educação em

Ciências e Educação Matemática

DOI: https://doi.org/10.33238/ReBECEM.2020.v.4.n.2.24146

constitui a última etapa da ATD: comunicação. A seguir, os metatextos são apresentados como resultado da pesquisa.

\section{Resultados: metatextos emergentes}

\subsection{Formação ambiental docente na perspectiva de uma educação crítica}

A primeira categoria emergente do processo de ATD contempla o total de 43 US, ao qual deteremos nosso olhar. A construção deste metatexto a partir das US centra a investigação na abordagem das concepções teórico-metodológicas de EA, que envolve desde a análise de PPC (Projeto Pedagógico do Curso), até o estudo da formação docente e o contexto escolar. De antemão, se apresentará no decorrer deste metatexto concepções de EA na formação docente, como tradicionalista, conservacionista, comportamentalista, naturalista e antropocêntrica. Aparecem também, questões sobre a formação políticofilosófica, a preocupação com a dimensão crítica e reflexiva da educação, ensino crítico e emancipatório, problematização sobre o desenvolvimento sustentável, sustentabilidade e socioambiental com a relação entre homem e natureza. Termina o metatexto a interdisciplinaridade e a EA para além de conteúdos de ecologia.

Neste ponto destacamos diálogos com teóricos sobre as concepções de EA na formação inicial, presentes em algumas US. Sauvé (2005) fez a identificação de quinze correntes de EA, para qual aponta como sendo uma forma geral de conceber e praticar a temática. Uma corrente pode incorporar uma pluralidade e diversidade de proposições, e, uma proposição pode corresponder a mais de uma corrente. Cada corrente tem características que as diferenciam umas das outras, apesar de compartilharem algumas em comum. A autora faz uma divisão das correntes, sendo que o primeiro grupo possui uma longa tradição em EA e eram dominantes nos anos 70 e 80 (naturalista; conservacionista; resolutiva; sistêmica; científica; humanista; ética) e o segundo grupo são correntes com preocupações mais recentes (holística; biorregionalista; práxica; crítica; feminista; etnográfica; eco-educação; sustentabilidade).

Em todos os níveis do campo educacional, os sujeitos adotam diferentes discursos sobre EA e possuem diversas maneiras de praticar suas ações de ensino. Rios-Ramiarina (2017, p. 4) aponta com os dados de sua pesquisa, que coexistem diferentes concepções e objetivos para a EA na formação inicial, algumas têm “[...] perspectivas conservacionistas e tecnológicas, outros que focalizam a estrutura social degradante do 
DOI: https://doi.org/10.33238/ReBECEM.2020.v.4.n.2.24146

meio ambiente. As práticas e abordagens em EA se voltavam para a instrumentalização e gestão de EA com metodologias de projetos, escolares ou não escolares".

É um leque amplo de perspectivas que podem enriquecer o trabalho docente e múltiplas concepções de EA que os educadores podem adotar, as quais precisam ser desenvolvidas na formação inicial para que o licenciando quando ver-se como professor da Educação Básica, possa ter clareza do seu fazer docente, ampliando a rede de educadores ambientais. Em pesquisas sobre formação docente, aparecem diferentes concepções de EA nos cursos de formação inicial, configurando-se em um ponto positivo para nossa investigação. Mas, há questões que precisamos refletir e dialogar:

Nessas pesquisas realizadas sobre formação de professores em EA, muitos
resultados evidenciaram uma concepção naturalista, conservacionista, sem
problematizar as questões relacionadas à degradação ambiental. Entretanto, há
destaque para as pesquisas, cujos resultados mostram a formação docente com
um nível elevado de criticidade e compromisso com uma EA emancipatória,
democrática e marcada pela luta por um mundo mais justo, humano e solidário
(LOBO-SANTOS; AIRES, 2017, p. 4).

É significativo encontrar concepções de EA variadas nos cursos de formação inicial, como a tradicionalista, conservacionista, comportamentalista, naturalista e antropocêntrica. Essa multiplicidade conceitual (chamadas também de macrotendências) que torna a EA plural revela sua diversidade interna, percebida na consolidação do campo, na tentativa de formular um conceito de EA abrangente o suficiente (LAYRARGUES; LIMA, 2014). Independente das variantes conceituais/concepções/correntes de EA, é necessário que os estudos apresentem uma abordagem significativa da temática. Assim, cabe assumir a defesa de diferentes posturas para que uma formação política de futuros professores aconteça. Tratar questões de política globalizante possibilita vias para a formação de educadores ambientais que não se acomodam frente à realidade e buscam a transformação. É indispensável, que ao constituírem-se como educadores ambientais, ultrapassem ações ingênuas e rompam com práticas demasiadamente conservadoras.

Para isso, argumentamos que a constituição docente exige uma reflexão crítica, questionadora. "Nesse contexto, cabe à formação inicial fornecer conteúdos teóricos, metodológicos e uma formação político-filosófica que possibilite ao futuro professor criar espaços educativos que contribuam para a transformação da realidade" (VIVEIRO; CAMPOS, 2007, p. 10). Nesse viés de mudanças não podemos pensar somente em fornecer instrumentos técnicos e metodológicos, precisamos contemplar a formação político-filosófica de educadores ambientais que possibilite a transformação desses educadores em líderes críticos nos espaços educativos (VIVEIRO; CAMPOS, 2007). 
DOI: https://doi.org/10.33238/ReBECEM.2020.v.4.n.2.24146

Silva e Carvalho (2009) trazem uma análise sobre os problemas ambientais pela visão dos licenciandos, apontam pouca articulação com as problemáticas ambientais e outros aspectos da realidade.

Os dados indicam que eles não articulam espontaneamente, e de modo mais
complexo, as causas dos problemas ambientais com diferentes dimensões da
realidade, tais como a de conhecimento, de prática política e de prática
valorativa, ou ainda com aspectos do enfoque CTS. Observamos que há, de
maneira geral, uma tendência a se compartimentalizar as causas da degradação
ambiental. Além disso, a maioria deles utiliza argumentos mais descritivos e
raramente questiona a maneira como construímos nossa relação com a natureza
ou como estamos organizados socialmente (SILVA; CARVALHO, 2009, p.
8).

Ainda é difícil contemplar a dimensão política da EA na formação docente. A articulação de temáticas ambientais ocorre de maneira complementar, muito individualizada pelos formadores. É preciso considerar o todo que a EA envolve, destacando os conflitos que existem com relação ao uso dos recursos naturais, pondo em evidência o envolvimento dos aspectos políticos, econômicos e sociais da questão ambiental. Um movimento inicial em busca do entendimento de uma concepção política de EA na formação pode dar-se com a compreensão do sujeito enquanto um ser que pensa e age criticamente. Nesse sentido,

[...] a EA (Crítica) pode ser compreendida como uma filosofia da educação que busca reorientar as premissas do pensar e do agir humano, na perspectiva de transformação das situações concretas e limitantes de melhores condições de vida dos sujeitos - o que implica mudança cultural e social (TORRES; FERRARI'; MAESTRELLI, 2014, p. 14).

O ensino e as práticas de pesquisa nos cursos de formação inicial de professores podem ser movimentos de grande contribuição para o desenvolvimento da postura crítica e reflexiva acerca das problemáticas ambientais. O professor é o principal agente para propiciar ao educando a possibilidade de desenvolver sua postura crítica e reflexiva, mediante as problemáticas sociais e ambientais vigentes, e, para isso, “[...] é importante que em seu processo de formação inicial e/ou continuada, ele tenha sido instigado a desenvolver o espírito crítico, o pensamento reflexivo e a atitude investigativa no seu processo de ensino-aprendizagem" (SILVA; PATACA, 2013, p. 2).

Para uma formação crítica, decorre a necessidade de um conjunto de fatores, em destaque a EA abordada como atividade curricular, com ênfase nas disciplinas e nos projetos relacionados à formação inicial de professores, para que os movimentos de pensar e agir ambientalmente possam ser articulados com o ensino básico, ampliando a rede de conhecimentos e sujeitos envolvidos com as questões de cunho ambiental, sendo 
DOI: https://doi.org/10.33238/ReBECEM.2020.v.4.n.2.24146

reforçado o entendimento de ambiental como relacionado às questões sociais, políticas e éticas.

\begin{abstract}
Ao sugerir a EA como disciplina obrigatória ou atividade curricular, acreditase que seja intenção dos órgãos gestores oferecerem ao futuro profissional da educação, não apenas os conteúdos desta temática, mas também subsídios para uma formação crítica que fortaleça sua postura ética, política e social justificativas sempre agregadas a essas indicações em diversos outros documentos e presentes nos projetos políticos pedagógicos em todos os níveis de ensino (CONTI; PASSOS, 2013, p. 5).
\end{abstract}

Como já exposto na introdução, a EA tem sua importância reconhecida e posta nos documentos oficiais da união, incluindo sua obrigatoriedade em todos os níveis educacionais. Em nível profissional, há vários componentes para a formação de uma visão mais ampla do ensino, da participação política e cidadã dos estudantes, numa perspectiva de EA crítica, que vem possibilitar a compreensão da crise de valores, auxiliar na construção do pensamento e epistemologia ambiental em diferentes áreas por professores em formação inicial. Mejía et al. (2013, p. 7) contribuem com essa visão:

\begin{abstract}
As análises dos cursos mostram que há um esforço caracterizado pelos temas escolhidos, referências teóricas e uso das abordagens da EA crítica, para que os Alunos entendam que há uma crise de valores, que o paradigma da razão como dominador mundial para a construção do pensamento ambiental através da epistemologia ambiental (tradução nossa).
\end{abstract}

Sustentamos a importância de uma EA crítica nas concepções ambientais desenvolvidas na escola e na formação inicial de professores, pois as concepções dos professores orientam a forma como as atividades estão desenvolvendo-se (ou irão desenvolver-se) na escola e na formação inicial. Lobo-Santos e Aires (2017, p. 8) evidenciam na análise de artigos de sua pesquisa, que essas ações ocorrem de forma pontual, em grande parte conteudista, em que se dá ênfase na descrição de problemas e classificação de componentes naturais, “[...] direcionada à preservação ambiental, sem o aprofundamento das questões que estão relacionadas a esta temática, como os aspectos sociais, políticos e econômicos, se afastando, assim, da politização e críticas sociais que é preocupação da EA crítica".

É preciso reconhecer a existência de uma diversidade de vertentes de EA, que pode ir de um comportamento modelado a uma percepção crítica. Mas não podemos deixar de reconhecer, como aponta Perlingeiro et al. (2013, p. 3), que ainda hoje “[...] encontramos vertentes de EA que vão desde aquela visão pautada na ideia de transmissão de conhecimentos para o "doutrinamento" de comportamento, passando por tendências intermediárias, até uma percepção crítica e transformadora”. 
DOI: https://doi.org/10.33238/ReBECEM.2020.v.4.n.2.24146

O levantamento bibliográfico da temática ambiental na formação de professores, realizada por Barros (2015), aponta a presença do modelo formativo crítico e transformador, sendo que nos trabalhos,

\section{[...] são enfatizados a carência de estudos na área de formadores ambientais, a necessidade de formar docentes capacitados para abordar a Educação Ambiental e seus conceitos, comprometidos com questões sociais, políticas e culturais, defendendo a falta de um modelo formativo intelectual crítico transformador (BARROS, 2015, p. 7).}

A formação de professores com um viés emancipatório, que estabeleça relação entre teoria e prática compreendida como práxis social, é um caminho para a perspectiva crítica transformadora versus a conservadora, buscando a superação da alienação (TOZONI-REIS, 2007). Não podemos negar a dificuldade de incorporação das discussões ambientais às práticas escolares, mas na tendência crítica podemos encontrar um caminho para mudanças na crise ambiental e nas relações de poder, como Freire (2018, p. 110) nos afirma, “[...] se a educação não é a chave para as transformações sociais, não é também simplesmente reprodutora da ideologia dominante". Portanto, estudantes imersos em uma visão de EA crítica, influenciados pela percepção do conhecimento científico, configuram-se em um dos desafios aos educadores (MEJÍA et al., 2013).

Repensar nossas ações, a organização da nossa sociedade a respeito das questões ambientais, é uma tarefa de resistência, em que ao invés de simplesmente legitimar estruturas políticas, econômicas e sociais que nos foram dadas, a EA faz emergir perguntas que precisam ser debatidas, refletidas e consideradas. Dessa forma, em âmbito social, ganha destaque a necessidade de pensar a educação como práxis social, onde todos que se preocupam com EA possam fazer suas próprias apropriações e usos, “[...] dependendo da concepção teórica, do lugar social ocupado pelos sujeitos e da compreensão de sociedade da qual se parta" (LOUREIRO, 2006, p. 150).

Considerar a realidade social e as concepções adotadas é fundamental para pensar como a EA crítica e transformadora pode ir além do espaço escolar, apontando para a construção de uma sociedade mais democrática, onde as instituições e os processos “[...] de formação da vontade política e de tomada de decisões sejam consistentemente permeáveis à participação de cidadãos livres e autônomos, a despeito da crescente complexidade e diferenciação característica das modernas sociedades" (TAVOLARO, 2005, p. 21).

O termo desenvolvimento sustentável fez-se presente em várias US, alguns desses fragmentos analisados apresentam as concepções dos licenciandos, que fazem uma 


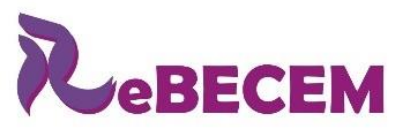

Revista Brasileira de Educação em

Ciências e Educação Matemática

DOI: https://doi.org/10.33238/ReBECEM.2020.v.4.n.2.24146

contraposição a exploração de recursos naturais e apontam que as tecnologias podem reduzir o prejuízo ambiental. Em um dos trabalhos analisados, muitos alunos de licenciatura apontam a possibilidade de "[...] construir processos de desenvolvimento sustentável, desde que os modelos produtivos sejam mediados pela preocupação com o efeito antrópico, sem o imediatismo da exploração errônea dos recursos naturais" (VELOSO; DAL-FARRA; VELOSO, 2017, p. 5). O trabalho dos autores citados afirma que houve também, em menor número, licenciandos que acreditam nas inovações tecnológicas como minimizadoras dos prejuízos ambientais, como equipamentos de redução de agentes poluentes.

Enquanto pesquisadores e professores formadores, percebemos, a importância de pensar a origem e as implicações do desenvolvimento sustentável. A definição da expressão surgiu no relatório de Brundtland, - documento elaborado pela Comissão Mundial sobre o Meio Ambiente e o Desenvolvimento - sendo reconhecida com um propósito que orienta a ação política e econômica mundial (VIZEU; MENEGHETTI; SEIFERT, 2012). O entendimento dominante do conceito está fundamentado em conciliação com o capitalismo, “[...] que deixa transparecer uma ambígua relação entre as condições históricas de sua emergência como ideia pretensamente reparadora da atual crise socioambiental e de seu real sentido de reforço da lógica do capital" (VIZEU; MENEGHETTI; SEIFERT, 2012, p. 570). Tozoni-Reis (2007) afirma que o desenvolvimento sustentável é um conceito ideológico que busca promover a ideia de sustentabilidade em uma realidade distorcida, negando o esgotamento de recursos, pois a sustentabilidade nessas situações se torna, em nossa visão, um termo contraditório, que busca apresentar uma salvação em prol do capitalismo, que se apresenta em crise de expansão.

Rios-Ramiarina (2017) percebeu a centralidade do mercado e a dicotomia homemnatureza, nos discursos e abordagens de EA entre os formadores de professores, destacando que alguns discursos de esfera individual sobre o comportamento humano são abordagens " [...] já bastante problematizadas pelo campo da EA, e a persistência deste discurso entre os formadores de professores sugere a necessidade de haver uma reflexão mais coletiva do tema, amadurecendo o seu tratamento na formação inicial destas instituições" (RIOS-RAMIARINA, 2017, p. 5). Percebemos mais uma vez, a importância de a EA ser contemplada durante a graduação e uma das apostas é na interdisciplinaridade, sendo essa colocada como caminho para compreender os problemas apontados pelos autores como socioambientais. 
DOI: https://doi.org/10.33238/ReBECEM.2020.v.4.n.2.24146

O termo socioambiental aparece em várias US, e para contextualizar, Fernandes e Sampaio (2008, p. 92) afirmam que a problemática socioambiental como campo de pesquisa, “[...] emana da discussão acerca da fragmentação do conhecimento e da necessidade de ruptura do modelo disciplinar em favor de um modelo mais integrativo", ou seja, coloca a interdisciplinaridade em evidência, como uma demanda. Os autores, ainda apontam que a resolução dos problemas socioambientais tem decorrência no próprio modelo econômico, que em outros tempos ignorou os danos ambientais, e que agora, passa a incorporar a destruição do ambiente ao preço dos produtos criando o que chamam de ecoeficiência - baseado no principio de poluidor-pagador. Assim como o desenvolvimento sustentável, o socioambiental também está atrelado ao capitalismo no que se refere à intencionalidade de um discurso voltado para a sustentabilidade.

Destacamos com base nas US, que com a contribuição de uma educação socioambiental, o educador pode repensar as ações da escola, suprindo a falta de conexões entre a EA com o ensino na educação básica, com relação à sustentabilidade e os conflitos políticos e econômicos. Licenciaturas que se voltam para a discussão de problemáticas ambientais nas ações educativas reforçam a importância de uma formação inicial que contribua para a aprendizagem escolar, explorando a pluralidade de saberes da educação e saberes ambientais necessários para a competência de ensinar na educação básica.

Assim, Silva, Gallo e Oliveira (2011) apontam que os cursos de licenciatura devem ofertar uma formação em que os futuros professores sejam capazes de desenvolver ações educativas com potencial ambiental, na educação básica e em outros espaços, de forma crítica, inovadora e contextual. É preciso desancorar a formação defasada em educação socioambiental, pois ela “[...] poderá resultar em práticas de educação ambiental fragmentada e reprodutivista nas escolas de Educação Básica" (SILVA; GALLO; OLIVEIRA, 2011, p. 7). Os mesmos autores ainda colocam que a educação socioambiental de futuros professores, nos diferentes níveis de ensino que orientem questões econômicas, sociais, políticas e culturais para construção de sociedades sustentáveis, têm suscitado mais estudos a respeito de sua necessária inserção no ensino superior, com objetivo de preparar os licenciandos em formação para desempenhar as questões ambientais em outros níveis educacionais e espaços interinstitucionais.

As US assinaladas nesta categoria, ainda apontam para o potencial que oficinas e outros projetos possuem, envolvendo problemas socioambientais e intencionando temáticas locais, como a temática do lixo e consumismo. Importante ressaltar nessas situações - considerando a aposta em uma EA crítica - que a escolha de temáticas deve 


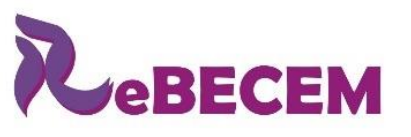

Revista Brasileira de Educação em

Ciências e Educação Matemática

DOI: https://doi.org/10.33238/ReBECEM.2020.v.4.n.2.24146

emergir democraticamente, partindo daquilo que os estudantes e/ou comunidade estejam dispostos a se engajar. Freire (2018) nos faz perceber "[...] a impossibilidade de vir a tornar-se um professor crítico se, mecanicamente memorizador, é muito mais um repetidor cadenciado de frases e de ideias inertes do que um desafiador" (p. 28-29), sendo que o papel do educador, em sua importância, é o de viver com a certeza que sua tarefa docente não é a de apenas ensinar os conceitos, mas o de ensinar a pensar.

Emerge para o metatexto construído até aqui, o argumento aglutinador da perspectiva teórica de uma EA crítica, que interliga os aspectos mencionados nesta categoria. Conforme reforça Tozoni-Reis (2007, p. 197), que "a educação, no âmbito da pedagogia crítica, tem como preocupação central a prática social transformadora, a construção de relações sociais plenas de humanidade dirigidas para a sustentabilidade social e ambiental".

O metatexto nos provoca a pensar uma formação docente baseada em práticas políticas e sociais, de transformação, que forme um professor capaz de compreender a diversidade de vertentes teóricas a respeito da EA, que se posicione frente à dominação do sistema, à modelação capitalista de desenvolvimento sustentável, um professor que pense práticas metodológicas interdisciplinares. Nesta perspectiva, a formação crítica dos sujeitos decorre de processos reflexivos, e a educação crítica, tem caráter essencialmente político, democrático, emancipatório e transformador. E se EA, é essencialmente educação, Tozoni-Reis (2007) nos coloca que não podemos tratá-la de forma neutra ambas são eminentemente políticas.

Argumentamos a relevância de pensar uma EA na formação inicial de professores que perpasse todas as disciplinas e níveis de ensino, que questione o significado de inserir uma nova disciplina para tratar questões ambientais devido à fragmentação de saberes. A EA na formação inicial pensada como articulação aos conteúdos curriculares na prática docente da educação básica, bem como a discussão ambiental e socioambiental em pesquisas que adotam um modelo reflexivo na formação de professores como estratégia didática permite um repensar sobre o currículo de formação. É sobre essas questões curriculares que trataremos na próxima categoria emergente de nosso processo de ATD.

\subsection{Ambientalização curricular para a formação inicial de professores}

Direcionamos nosso olhar para 38 US que emergem para esta categoria Ambientalização curricular para a formação inicial de professores. A construção e a 


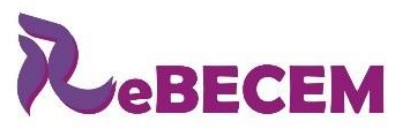

Revista Brasileira de Educação em

Ciências e Educação Matemática

DOI: https://doi.org/10.33238/ReBECEM.2020.v.4.n.2.24146

discussão desse metatexto estão centradas nos movimentos curriculares, sendo o principal articulador de uma formação inicial ambientalizadora. Apresentaremos nesta categoria interlocuções teóricas com autores que abordam distintas concepções e perspectivas da EA e suas relações com os currículos dos cursos de formação de professores, e seus contextos formativos nas instituições brasileiras. Assumimos que o currículo não é uma seleção de conteúdos, e sim, uma produção cultural por estar inserido nos diferentes significados que conferimos ao mundo. Portanto, "o currículo não é um produto de uma luta fora da escola para significar o conhecimento legítimo, não é uma parte legitimada da cultura que é transportada para a escola, mas é a própria luta pela produção do significado" (LOPES; MACEDO, 2011, p. 93).

O currículo é uma construção coletiva, que abrange os mais diversos aspectos e questões que chegam ao ambiente educacional, seja qual for seu nível de ensino (infantil, fundamental, médio ou superior). Independente disso, todo e qualquer currículo que venha a ser construído na e pela instituição de ensino, precisa contemplar uma série de objetivos e especificidades instituídas pelos documentos oficiais do Estado, a exemplo da Lei de Diretrizes e Bases da Educação Nacional (LDBEN) e as Diretrizes Curriculares Nacionais (DCN). Esses documentos regem princípios, fundamentos e procedimentos que orientam as instituições educacionais quanto à organização, articulação, desenvolvimento e avaliação de suas propostas pedagógicas.

Retomando o exposto nas considerações iniciais deste trabalho, temos, segundo as normas das leis e diretrizes mencionadas, um parâmetro de implementação da EA no contexto educacional. Dessa forma, ao buscar compreender como se mostra a EA na formação inicial de professores nas diferentes linhas temáticas dos anais do ENPEC, a emergência desta categoria reforça a necessidade de refletir o caráter estruturante do currículo para as atividades pedagógicas e desenvolvimento do trabalho do professor.

Cabe ressaltar que a aposta é um currículo crítico, que supere o foco no processo de configuração curricular técnica que é visto como grade, relação de disciplinas e conteúdos, métodos e técnicas, para um currículo com um sentido mais amplo, que perpasse todas as ações da instituição educativa (TORRES; FERRARI; MAESTRELLI, 2014). Um viés apontado nas US como arcabouço para a estruturação de um currículo crítico é a interdisciplinaridade.

A interdisciplinaridade esteve presente em muitas US, relacionadas aos cursos que formam professores e ao contexto escolar, pensada e apontada como estratégia para lidar com a diversidade de conteúdos na prática educativa, constituindo-se como um 


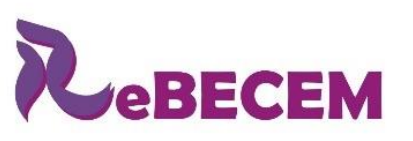

Revista Brasileira de Educação em

Ciências e Educação Matemática

DOI: https://doi.org/10.33238/ReBECEM.2020.v.4.n.2.24146

importante diferencial (VIVEIRO; CAMPOS, 2007), bem como, para formar ambientalmente professores e alunos. A interdisciplinaridade e a EA, ambas colocadas em prática, podem ser consideradas “[...] ferramentas na formação de professores e alunos, favorecendo o desenvolvimento do espírito crítico e de sujeitos mais preparados para debaterem questões que envolvam diferentes aspectos como políticos, econômicos, sociais e ambientais" (MARTINS et al., 2017, p. 9).

Algumas pesquisas com alunos de licenciatura, por exemplo, reforçam aspectos sobre a necessidade de realizar-se um trabalho interdisciplinar sobre problemáticas ambientais, e não as tratar como conteúdo de uma disciplina isolada sobre EA. Assim, necessitamos refletir sobre a inserção de uma nova disciplina para tratar questões ambientais, como aponta a US a seguir:

[...] a simples inserção de uma "nova disciplina" não garantiria aos alunos uma melhor formação e cabe indagar se os conteúdos dessa disciplina abordariam questões socioambientais. Caso contrário, correríamos o risco de propor uma disciplina que só seria "nova" formalmente, mas continuaria possuindo conteúdos cuja orientação cartesiana fragmenta os saberes e inviabiliza um tratamento coerente com a complexidade das questões ambientais (SILVA; GALLO; OLIVEIRA, 2011, p. 4).

Muitas pesquisas apontam, segundo Barros e Quirós (2015), por meio de análises, a falta da interdisciplinaridade e a visão reducionista de currículo no que tange a EA na formação inicial. A inclusão da EA no currículo de licenciandos de forma interdisciplinar é um dos caminhos na busca de soluções para os problemas apontados como socioambientais com a contribuição da educação, como por exemplo, a constituição de um grupo de estudos com estratégias didáticas sobe temas ambientais na formação inicial. Outro caminho para a formação de professores com perspectiva interdisciplinar no contexto ambiental pode ser o ensino por pesquisa e a participação coletiva. Projetos e saberes articulados com as questões ambientais têm na interdisciplinaridade, bem como na transversalidade, muitas potencialidades.

$\mathrm{Na}$ análise também emerge a configuração curricular seguindo a perspectiva freireana sobre abordagens temáticas, que "[...] consiste em uma forma de pensar e fazer currículo de modo reflexivo e crítico, integrando teoria e prática, pesquisa e intervenção pedagógica” (TORRES; FERRARI; MAESTRELLI, 2014, p. 24). Para que as temáticas ambientais sejam inseridas e estejam presentes nos cursos de licenciatura é importante o processo de ambientalização dos currículos para a formação de docentes com apropriação das abordagens interdisciplinares, transdisciplinares e multidisciplinares. "É preciso avançar políticas e práticas pedagógicas comprometidas com a formação de docentes para 


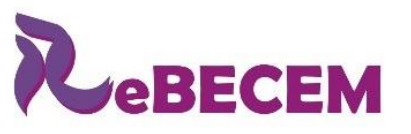

Revista Brasileira de Educação em

Ciências e Educação Matemática

DOI: https://doi.org/10.33238/ReBECEM.2020.v.4.n.2.24146

exercer sua função transformadora, para contribuir com a democratização da sociedade e propiciar a apropriação do saber ambiental [...]” (SILVA; FARIAS, 2015, p. 6). Decorre que a formação de educadores ambientais necessita de um trabalho bem amparado em termos de interdisciplinaridade e de um currículo bem estruturado.

Há estudos significativos sobre a análise de PPC, com investigações sobre a abordagem das concepções teórico-metodológicas de EA e sobre a constituição de profissionais reflexivos quanto à sustentabilidade, pois, a EA como atividade curricular pode contribuir para uma formação crítica. Em um desses estudos, “os PPC dos cursos analisados, em sua maioria, trazem o termo EA. No entanto, estão ausentes explicitações da abordagem teórico-metodológica que se pretende tratar, não havendo assim, uma orientação coletiva, institucional para a formação de professores em EA" (RIOSRAMIARINA, 2017, p. 4). Nesse viés, Leite e Rodrigues (2011, p. 9) mencionam que há grande ausência da EA nos cursos de formação de professores da área de Química “[...] caracteriza-se como um dos obstáculos para o desenvolvimento da Educação Ambiental na educação básica [...]" tendo em vista a estrutura dos cursos de graduação, que estão fortemente focados nos conceitos sem fazer menção a outros aspectos relacionados à temática ambiental.

Neste trabalho, sobre a EA na formação inicial de professores, temos evidenciado até aqui que os artigos selecionados em nossa busca nas atas do ENPEC apontam para a pouca inserção da temática ambiental nas licenciaturas. É possível perceber dificuldades para inserção de temas ambientais nos cursos de formação de professores segundo as recomendações do PNEA, decorrentes da superficialidade da EA no currículo dos cursos. Por isso, torna-se importante ancorar compreensões sobre a ambientalização curricular, e estar em questionamento constante: será que a dimensão ambiental como proposta de abordagem presente nas ementas das disciplinas assegura seu tratamento? Pois, “[...] sabemos que a simples inserção de disciplinas relacionadas ao meio ambiente, não garante a ambientalização curricular, há outros fatores importantes a serem analisados [...]" (SILVA; FARIAS, 2015 p. 5). Um currículo ambientalizado não dá seguridade de que a abordagem ambiental é de fato realizada, ao mesmo tempo, Dickmann (2017, p. 66) afirma que ambientalização curricular não é disciplinarização, ou seja, é preciso tomar “[...] as questões socioambientais como um processo de constituição da presença crítica das temáticas ambientais no currículo, de forma multi, inter e transdisciplinar [...]”.

O que podemos compreender como ambientalização curricular? Para Mota, Cousin e Kitzmann (2018, p. 209), “[...] o processo de ambientalização pode ser 


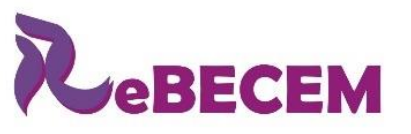

\title{
Revista Brasileira de Educação em \\ Ciências e Educação Matemática
}

DOI: https://doi.org/10.33238/ReBECEM.2020.v.4.n.2.24146

compreendido como a integração da temática socioambiental de forma articulada, em todos os níveis e modalidades, do processo educativo, em caráter formal e não formal [...]". Os autores apontam que a ambientalização curricular está relacionada ao eixo do ensino com a integração de valores (ambientais, éticos, sociais) e do conhecimento nos currículos, enquanto a institucional (ou sistêmica) envolve as dimensões da pesquisa, da extensão, do ensino e da gestão, sendo um processo globalizante da ambientalização. Ainda em resposta à pergunta, o autor de um dos artigos analisados em nossa pesquisa menciona:

\begin{abstract}
Entendemos por ambientalização curricular a incorporação de temas e conteúdos ambientais multidisciplinares, tomados como conceitos, procedimentos, atitudes e valores que se configuram na matriz curricular, em planos de estudos de cursos de graduação e de pós-graduação, em planos de disciplinas, que constituem o percurso acadêmico de formação de um dado profissional (STALLONY et al., 2011, p. 2-3).
\end{abstract}

Além disso, existem questões epistemológicas a serem consideradas, afinal a contribuição na inserção de temas, disciplinas e conteúdos na formação dos alunos podem vir acompanhadas de limitações. A relação do currículo com a EA vai além de uma ambientalização em sua organização estrutural, pois “[...] independentemente dos conhecimentos disciplinares desta ou daquela área, o desenvolvimento da leitura, da escrita, da argumentação e da oralidade contribuem para a ambientalização do professor" (SOUZA, 2011, p. 238).

Esse processo de ambientalização (tanto do currículo, quanto do professor e do aluno), requer um olhar atento para uma abordagem de EA que permeie os diferentes níveis educacionais em seus diferentes tempos. Os obstáculos da EA na educação básica, por exemplo, podem ser decorrentes, principalmente, da dificuldade em inserir a temática ambiental na estrutura dos cursos de graduação. A EA no currículo de uma licenciatura pode ser perceptível em termos de se ter ou não uma ambientalização curricular. Em nossa pesquisa identificamos em 12 dos artigos selecionados, estudos voltados para esta questão, e o que se tem percebido é a ausência, ou a desconexão, sem metodologia ou intencionalidade definida para trabalhar com a EA.

Outro aspecto relevante é que muitas vezes a EA vem a ser abordada somente na formação continuada, ou ainda, experiências ambientais vividas somente quando o professor buscou uma pós-graduação. Assim, destacamos que somente a formação continuada não dará conta da ambientalização escolar. É preciso um conjunto, a iniciar pela inquietação ambiental dos professores ainda na formação inicial, para que na 


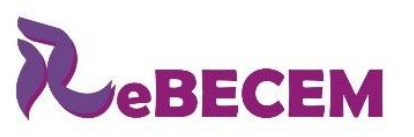

Revista Brasileira de Educação em

Ciências e Educação Matemática

DOI: https://doi.org/10.33238/ReBECEM.2020.v.4.n.2.24146

formação continuada busquem dar continuidade aos trabalhos que vem sendo realizados e acrescentar novas ideias aos seus projetos.

Em relação à EA ser inserida durante a formação inicial, outro estudo indica sua ocorrência de maneira secundária, como conteúdo ou abordagem e relacionada nas disciplinas pedagógicas (VIVEIRO; CAMPOS, 2007). A análise de ementas das disciplinas feita pelos autores citados, referentes a um curso de licenciatura, apontam modalidades didáticas utilizadas nas aulas, onde muitas vezes há predominância de aulas expositivas e de laboratório na formação, tendo, deste modo, pouca discussão acerca de modalidades didáticas possíveis. E, ainda, "as discussões são pautadas ou em referências antigas, com enfoque ecológico, ou nos conteúdos abordados pelos PCN, não envolvendo as mais recentes discussões na área de EA" (VIVEIRO; CAMPOS, 2007, p. 10). Em contraponto, outra pesquisa indica que há cursos que adotam no currículo de formação, o modelo reflexivo na formação de professores como estratégia didática para a discussão socioambiental (BARROS; QUIRÓS, 2015).

Algumas US apontam para divergência de conceitos, abordagens e caminhos metodológicos no trabalho com a problemática ambiental em relação com o aprendido em alguns cursos de licenciatura coloca em dúvida as convicções disciplinares na formação inicial de professores. Isso leva muitos licenciandos a não considerarem o tratamento de questões ambientais como conteúdo de sua disciplina. Esse fato fica evidente quando lhes sugerem um trabalho interdisciplinar para tratar de aspectos da problemática ambiental em suas atividades de ensino. O estudo de Silva e Carvalho (2009) aponta que estágios nas disciplinas de práticas de EA são uma oportunidade para trabalhar com a relação teoria e prática com pesquisa. Dessa forma, “[...] para vários estagiários, a problemática ambiental traz termos, conceitos, abordagens e caminhos metodológicos diferentes daqueles aprendidos e intensivamente trabalhados no curso de licenciatura [...]” (SILVA; CARVALHO, 2009, p. 11), questionando as convicções disciplinares e relegando um entendimento científico amplo, apontando para outras áreas, trazendo para discussão conhecimentos antes deixado em segundo plano.

\footnotetext{
A ideia de que o domínio de conteúdos da ciência de referência seja suficiente para que práticas educacionais sejam bem sucedidas demonstra uma compreensão dicotomizada entre teoria e prática e, no caso específico da EA, que o simples domínio de conteúdos ecológicos daria conta do ensino de temas de EA na escola. Tal dicotomia fica clara quando observamos a colocação dos conhecimentos pedagógicos (PERLINGEIRO et al., 2013, p. 6).
}

Além de apontar a dicotomia entre a teoria e a prática entre os conteúdos de ecologia e os temas de EA, alguns autores indicam que há ainda muito presente, a visão 
DOI: https://doi.org/10.33238/ReBECEM.2020.v.4.n.2.24146

de EA segundo os conhecimentos biológicos/ecológicos, os quais não necessariamente dialogariam com os pedagógicos. Portanto, outro tema curricular identificado no nosso estudo é a aproximação da EA e ecologia, em que, um aspecto é a falta de tradição em tratar questões de política globalizante (STALLONY et al., 2011). Persistem também, em algumas situações, confusões entre a EA e a ecologia, na qual cabe questionar: como construir uma concepção reflexiva e crítica num currículo marcado pela concepção biológica? A formação ambiental precisa ir além da ecologia nos conteúdos curriculares e uma opção é perpassar todas as disciplinas e níveis de ensino.

Primeiramente consideramos que a princípio os estudantes confundem
educação ambiental com ecologia ao responderem que o curso possui
discussões voltadas para as questões da educação ambiental, e logo depois
listam conteúdos da ecologia descontextualizados da realidade social. Isso
revela que ainda é muito forte a concepção Biológica de educação ambiental
no currículo do curso, o que dificulta aos estudantes construírem uma
concepção de educação socioambiental reflexiva e crítica no contexto do curso
(SILVA; GALLO; OLIVEIRA, 2011, p. 6).

Assim a responsabilidade por tratar os temas da EA para compreensão do ambiente, quando se trata de um curso da área biológica, fica ao encargo da área do ensino ou de ecologia? A análise dos currículos de alguns cursos da área de Ciências Biológicas esteve em foco, e os autores Perlingeiro et al. (2013); Stallony et al., (2011) Silva, Gallo e Oliveira (2011); Viveiro e Campos (2007), verificaram que há predominância da abordagem de EA na disciplina/área de ecologia. Em outros casos, quando a temática ambiental está restrita as disciplinas pedagógicas no curso de formação de professores, as estratégias e modalidades para discussões de EA podem e precisam ir além do enfoque ecológico e do que diz o PCN, bem como, superar a secundariedade dos aspectos ambientais trabalhados como conteúdo/propostas de abordagem.

Lopes e Zancul (2011, p. 10) afirmam que apesar de a EA estar presente nas disciplinas de alguns cursos, os mesmos não atendem às recomendações da PNEA ao que se refere "[...] à inserção da dimensão ambiental nos currículos de formação de professores, em todas as disciplinas, o que nos leva a questionar quais as dificuldades para a inserção efetiva dos temas ambientais nesses cursos". Nesse sentido, Loureiro e Franco $(2014$, p. 160) contribuem para compreendermos a “[...] práxis, no sentido de que a visão de mundo de cada um é a máxima consciência possível da sua atividade e das relações sociais por meio das quais interage com a natureza e a sociedade para produzir e reproduzir sua existência em situações historicamente dadas".

Assim, a educação dita como ambiental na formação inicial pode vir a contribuir para a articulação com os conteúdos curriculares na prática docente da educação básica 


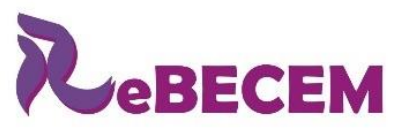

Revista Brasileira de Educação em

Ciências e Educação Matemática

DOI: https://doi.org/10.33238/ReBECEM.2020.v.4.n.2.24146

por meio da aposta de ambientalização. Ambientalização curricular dos professores, dos alunos, das instituições educacionais... e finalmente da sociedade. Por fim, percebemos a importância da ambientalização curricular oportunizando a dimensão do currículo para além de um PPC e a organização de disciplinas. O currículo, aqui compreendido na prática, como tudo aquilo que acontece na instituição educacional: os conteúdos trabalhados nas disciplinas, as atividades extraclasse, os projetos, as oficinas e palestras, a sala de aula, a sala dos professores, a cozinha, os ambientes comuns, todos os ambientes e atividades de lazer, as pessoas e tudo aquilo que faz parte da rotina de atividades do lugar. Idem ao currículo, as questões ambientais perpassam todas as áreas, e por isso o argumento aglutinador desta segunda categoria é um currículo que tenha uma ambientalização compreendida como interdisciplinar, de forma que a EA venha a ser abordada no contexto educativo. Desse modo, a categoria 3 nos direciona a pensar em como essa EA pode ser abordada pelos professores.

\subsection{Estratégias didáticas para temas ambientais na formação docente}

A terceira categoria em estudo compõe 26 US. No terceiro metatexto as US mostraram a temática ambiental relacionada aos conceitos científicos. Além disso, destacamos a importância de estratégias e modalidades didáticas no processo formativo de professores, bem como a utilização dessas estratégias nas aulas, levando em conta a EA como um instrumento para a aquisição de valores e atitudes frente aos problemas ambientais.

Dentre as US, algumas apontaram para a necessidade de compreender como a abordagem da temática ambiental é realizada pelos professores que se interessam pelo tema. Leite e Rodrigues (2011) apontam que ocorre em casos pontuais, como estágios. Cabe questionar como os docentes desenvolvem a temática ambiental nas suas aulas, e, para isso Viveiro e Campos (2007, p. 10) colocam na sua pesquisa que "pelas falas dos docentes, até o momento, não há elementos suficientes que permitam discutir de que forma esses professores desenvolvem a temática ambiental em suas aulas, ou de que EA estão falando". Dessa forma, pensando na necessária abordagem da EA, poderíamos apostar em diversas estratégias de EA, como por exemplo atividades de campo, que permitem o contato com o ambiente gerando possibilidade de sensibilizar os alunos acerca das problemáticas ambientais (VIVEIRO; CAMPOS, 2007). 


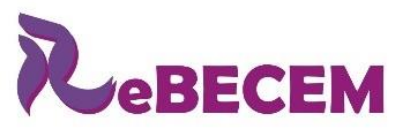

Revista Brasileira de Educação em

Ciências e Educação Matemática

DOI: https://doi.org/10.33238/ReBECEM.2020.v.4.n.2.24146

Atividades de campo nos projetos de EA podem emergir como possibilidade para os professores interagirem entre áreas numa via interdisciplinar, e ir além da complementação de conceitos científicos, pois um aspecto presente nas US é o questionamento de para quem caberia a responsabilidade da problemática ambiental na escola. Muitas vezes ocorre dos professores de determinada área apontarem que a temática deva ser abordada exclusivamente por professores de outras especialidades (SILVA; CARVALHO, 2009). É uma visão a ser desconstituída, visto que a EA, segundo parâmetros legais já destacados anteriormente, deve ser tratada com caráter interdisciplinar.

Destacamos ainda a carência de estudos e de processos formativos para a EA na formação de professores nas pesquisas estudadas, visando à formação de educadores ambientais. Deste modo, "A formação de educadores ambientais é importante e se faz indispensável em função de necessitarmos de pessoal qualificado para mitigar ou solucionar os problemas da intervenção humana no mundo natural" (STALLONY et al., 2011, p. 04). Mas ao formar educadores ambientais, cabe intencionar a possibilidade de desenvolver a criticidade em outros sujeitos, como os alunos, para que uma EA transformadora seja possível na sociedade e para que as reflexões e decisões ambientais não fiquem somente a cargo de um corpo técnico qualificado e centralizado.

Visamos, com a EA, dar oportunidade de que todos os cidadãos que compõem a comunidade consigam interpretar os discursos técnicos, muitas vezes plausíveis de manipulação, para que se posicionem frente às questões de impacto social. Ao ensinar, precisamos buscar que os nossos alunos se transformem, com a educação que realizamos, em sujeitos mais críticos, pois "a cidadania que queremos é aquela que passa a ser exercida através de posturas críticas na busca de modificações do ambiente natural - e que estas sejam, evidentemente, para melhor" (CHASSOT, 2011, p. 140).

O cotidiano é muito mais complexo de se compreender do que o educador ou o formador muitas vezes pode pressupor. Dai a importância de entender o senso comum e buscar formas de trabalhar com e a partir desses entendimentos iniciais, envolvendo as temáticas ambientais. Silva e Farias (2015) colocam que especificamente sobre a inclusão das temáticas ambientais na formação de um professor de Química, por exemplo, é necessário superar o senso comum, para que, então, seja possível compreender a complexidade da realidade por meio de situações reais e concretas do cotidiano.

Partindo do cotidiano os estudantes podem vir a ser imersos em uma visão da EA crítica, influenciados pelo conhecimento científico, em um movimento chamado por 
DOI: https://doi.org/10.33238/ReBECEM.2020.v.4.n.2.24146

Chassot (2011) de alfabetização científica. Para tal, a estrutura de um curso de licenciatura precisa abranger conhecimentos científicos, pedagógicos, didáticos e ambientais em seus componentes (MEJÍA et al., 2013). Estabelecer relações entre conceitos científicos e o cotidiano dos alunos não é tarefa simples, por isso reforçamos mais uma vez a importância de a EA ser comtemplada na formação inicial em cursos de Licenciatura. No caso das disciplinas, trata-se não apenas de ensinar os conceitos científicos isolados, mas relacioná-los e inseri-los na vida dos alunos. Uma formação inicial adequada em relação a EA auxilia os professores no desenvolvimento da capacidade de selecionar temas que sejam pertinentes a sua disciplina e que contemplem questões ambientais atuais (LEITE; RODRIGUES, 2011). Além disso, o professor buscando a participação dos seus alunos pode propor que os temas de estudo emerjam a partir do diálogo em sala de aula, tomando decisões coletivas com estudantes sobre o que investigar, pois "[...] o educador democrático não pode negar-se o dever de, na sua prática docente, reforçar a capacidade crítica do educando, sua curiosidade, sua insubmissão" (FREIRE, 2018, p. 28).

Nas primeiras tentativas de inserção da problemática ambiental nas atividades de ensino pelos licenciandos, são comuns a exemplificação e a ilustração dos conteúdos específicos, essa perspectiva constitui-se como uma primeira tentativa de tratar aspectos ambientais em suas atividades de ensino (SILVA; CARVALHO, 2009). Esse movimento precisa ser instigado e valorizado, compreendendo a importância de estimular o pensamento dos alunos em relação às questões que abrangem o ambiente. Cabe destacar que, ao tratar de temas ambientais, estamos também nos referindo intrinsicamente a temas sociais, com relação à questões que possibilitam abordagens políticas, econômicas e tecnológicas, onde em momento algum se opta por temas em detrimento dos conceitos científicos, mas sim, ao desenvolver este tema seja para instigar o pensamento dos estudantes à tomada de decisões e proposta de soluções.

Com esse raciocínio, destacamos a abordagem Ciência, Tecnologia e Sociedade $\left(\mathrm{CTS}_{\text {ou }} \mathrm{CTSA}^{5}\right.$ ), em que as atividades de CTS podem contribuir para o desenvolvimento do raciocínio crítico e construção de conhecimentos científicos articulados com o meio ambiente na perspectiva do ensino por pesquisa. Ribeiro, Genovese e Colherinhas (2011) destacam que uma atividade investigativa pautada nesses pressupostos é capaz de estabelecer um ambiente onde os alunos podem construir e desenvolver conhecimentos,

${ }^{5}$ Ciência, Tecnologia, Sociedade e Ambiente (CTSA). Existe um embate teórico sobre a sigla incluir ou não o termo "Ambiente". 


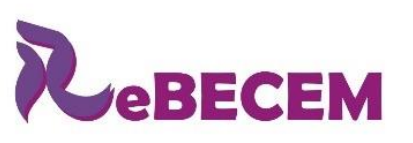

Revista Brasileira de Educação em

Ciências e Educação Matemática

DOI: https://doi.org/10.33238/ReBECEM.2020.v.4.n.2.24146

apartir de e/ou com discussões argumentativas e problematizações, que exigem raciocínio crítico, e os aproxima de uma visão mais abrangente ao que se refere à construção do conhecimento científico. Esse contexto sinaliza "[...] a viabilidade de se trabalhar tal abordagem em sala de aula, lembrando, é claro, que adequações à perspectiva do Ensino por Pesquisa devem ser realizadas pelos professores, licenciandos e pesquisadores que venham empregar tal proposta" (RIBEIRO; GENOVESE; COLHERINHAS, 2011, p. 12).

Também há um artigo analisado que apresenta experiências teóricas e práticas envolvendo CTS, alfabetização científica e visões de EA no ensino por meio de Projetos de Extensão na formação docente, onde a participação dos licenciandos em formação inicial pode contribuir promovendo momentos de aprendizagens mais democráticos, que os auxilie na problematização de concepções positivistas da ciência. Dessa forma,

[...] o fato do projeto de extensão trabalhar com EA na formação docente em ciências, pode também contribuir para aprofundar discussões de diferentes correntes teóricas do Ensino de Ciências como o movimento ciência, tecnologia e sociedade (CTS) letramento/alfabetização científica, questões sócio científicas, temas controversos no ensino de ciências, que se aproximam ao entender a função social do ensino de ciências e que geram pontos de encontro com determinadas visões de EA (JULIANI; SANTOS, 2015, p. 7).

Os entendimentos sobre a temática ambiental têm relevância nos nossos trabalhos porque nos colocam na posição de questionamento em relação ao significado que atribuímos à elaboração e aplicação do conhecimento científico nas práticas educativas. As compreensões que temos podem se tornar obstáculos na abordagem da temática ambiental num viés mais complexo e real. Dentre essas dificuldades, destacam-se as abordagens da relação homem e natureza em relação ao conhecimento científico restrito ao factual e conceitual (SILVA; CARVALHO, 2009). Assim, surgem algumas saídas para que o movimento de ambientalização possa ocorrer, como estratégias já mencionadas e outras modalidades didáticas e pedagógicas.

As modalidades didáticas utilizadas em aula foram sinalizadas em algumas US. Elas apontam que a temática ambiental não pode ficar restrita as disciplinas pedagógicas no curso de formação de professores, precisam ir além do que diz o PCN e extrapolar o enfoque ecológico, perpassando outras estratégias e modalidades para as discussões de EA. Viveiro e Campos (2007) realizaram a análise de ementas das disciplinas de um curso de Licenciatura e identificaram algumas modalidades didáticas inseridas nas disciplinas desse curso, tendo como margem tanto as modalidades utilizadas pelo professor para ministrar sua aula, quanto às discutidas com os alunos para serem inseridas nas suas aulas 
DOI: https://doi.org/10.33238/ReBECEM.2020.v.4.n.2.24146

na Educação Básica. Os autores concluíram que há pouca discussão de modalidades didáticas nas disciplinas analisadas no PPC, e que existe uma predominância de aulas expositivas na formação dos licenciandos.

A intenção das modalidades didáticas é de que sejam utilizadas como diferentes estratégias para o trabalho do professor, no processo de ensino e aprendizagem, influenciando a formação do professor. Não podemos deixar de mensurar as potencialidades e limitações de inserir modalidades didáticas nas aulas, pois "[...] para além da inserção, deve haver fundamentação, reflexão e discussão acerca de quais modalidades utilizarem, como e em que momento inseri-las no contexto das aulas, de que forma explorá-las [...]" (VIVEIRO; CAMPOS, 2007, p. 8). Enfim, cada professor deve adequar reflexivamente as modalidades didáticas conforme sua prática e experiência, de modo a sentir que sua aula é a melhor possível.

$\mathrm{O}$ argumento que aglutina esta terceira categoria são as estratégias didáticas utilizadas pelos professores em suas práticas de ensino para trabalhar as temáticas de EA. As estratégias ao perpassarem as salas de aula, pensando o desenvolvimento da abordagem ambiental, visam buscar várias relações, como os conceitos científicos, senso comum e questões sociais. O desafio que se coloca é o de pensar a estrutura de um curso que seja ambientalizado no processo formativo dos licenciandos, ao que se refere ao conhecimento científico, pedagógico e didático, de forma que os (futuros) professores possam aliar a EA em suas estratégias de ensino. É um movimento complexo, talvez idealista, onde muitas mudanças estruturais e básicas precisam ocorrer, sendo a interdisciplinaridade apontada como um possível avanço nessa direção.

\section{Considerações finais}

O estudo empreendeu a importância de investigarmos a EA na formação inicial de professores, visto a relevância da temática e as determinações das Diretrizes em função da Lei no 9.795/1999. A análise dos trabalhos nas atas dos encontros do ENPEC é significativa para a pesquisa por tratar-se do maior evento nacional na área de ensino de Ciências. As compreensões teóricas emergentes, após investigação detalhada do fenômeno, permitiram uma compreensão de possibilidades que se mostram e potencializam a pesquisa. Os argumentos aglutinadores possibilitaram a percepção do diálogo existente entre os temas que compõe cada categoria final, bem como as três categorias convergem para a possibilidade de evidenciarmos que a interdisciplinaridade 


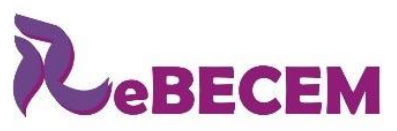

Revista Brasileira de Educação em

Ciências e Educação Matemática

DOI: https://doi.org/10.33238/ReBECEM.2020.v.4.n.2.24146

esteve posta do início ao fim da investigação, como conceito substancial que dá base para o trabalho com a temática ambiental.

Destacamos a importância de realizar a busca dos dados sobre a EA em todos os trabalhos do evento, não só na área temática de referência, tendo como primeira evidência do estudo a transversalidade e a interdisciplinaridade do tema ambiental investigado. Quanto à EA na formação inicial, apesar do número reduzido de trabalhos encontrados (18), os mesmos podem dar subsídios enriquecedores ao processo de diálogo acerca das questões pretendidas, como foi possível perceber pelo panorama apresentado. Desse modo, com o processo investigativo de compreender o fenômeno em estudo, reforçamos nosso argumento sobre a importância de compreender o papel da EA na formação inicial de professores.

Considerando todo o exposto no decorrer do estudo, finalizamos argumentando que, como pesquisadoras, percebemos o caráter transversal da temática em estudo durante a seleção do corpus e a interdicisplinaridade durante a análise dos artigos selecionados. Dessa forma, compreendemos que a EA: i) se mostra na formação inicial de professores nos anais do ENPEC estudados como perspectiva teórica para uma educação crítica, transversal e interdisciplinar; ii) com compreensão da necessidade de realizar a ambientalização curricular; e, iii) preocupada com o processo formativo referente às estratégias didáticas utilizadas para tratar temáticas ambientais.

\section{Referências}

BARROS, T. G. E.; QUIRÓS, W. P. Estado da Arte sobre as pesquisas de formação de professores na Educação Ambiental. In: ENCONTRO NACIONAL DE PESQUISA EM EDUCAÇÃO EM CIÊNCIAS, 10, 2015, Águas de Lindóia. Anais... Águas de Lindóia: Abrapec, 2015. p.1-8.

BEHREND, D. M.; COUSIN, C. S.; GALIAZZI, M. C. Base Nacional Comum Curricular: o que se mostra de referência à educação ambiental? Ambiente \& Educação, Rio Grande, v. 23, n. 2, p. 74-89, 2018.

BRANDÃO, C. R. Aqui é onde eu moro, aqui nós vivemos: escritos para conhecer, pensar e praticar o município educador sustentável. Brasília: MMA, Programa Nacional de Educação Ambiental, 2005.

BRASIL, Lei $\mathbf{n}^{\mathbf{0}}$ 9.795, de 27 de abril de 1999. Dispõe sobre Educação Ambiental e institui a Política Nacional de Educação Ambiental, e dá outras providências. Diário Oficial da União. Brasília, DF, 1999.

CHASSOT, A. Alfabetização Científica: questões e desafios para a educação. Ijuí: Editora Unijuí, 2011. 


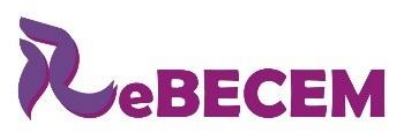

\section{Revista Brasileira de Educação em \\ Ciências e Educação Matemática \\ ISSN 2594-9179}

DOI: https://doi.org/10.33238/ReBECEM.2020.v.4.n.2.24146

CONTI, R. P.; PASSOS, M. M. A educação ambiental na formação de professores: um olhar nas licenciaturas. In: ENCONTRO NACIONAL DE PESQUISA EM EDUCAÇÃO EM CIÊNCIAS, 9, 2013, Águas de Lindóia. Anais... Águas de Lindóia: Abrapec, 2013. p. 1-6.

DICKMANN, I. Pedagogia da (in)disciplina ambiental: desafios político-pedagógicos na formação de educadores ambientais no ensino superior. Rev. Eletrônica Mestr. Educ. Ambient., Rio Grande, v. 34, n. esp. EPEA, p. 55-70, 2017.

FERNANDES, V.; SAMPAIO, C. A. C. Problemática ambiental ou problemática socioambiental? A natureza da relação sociedade/meio ambiente. Desenvolvimento e meio ambiente, Curitiba, v. 18, n. 1, p. 87-94, 2008.

FREIRE, P. Pedagogia da Autonomia: Saberes necessários à prática educativa. 57. ed. Rio de Janeiro/São Paulo: Paz e Terra, 2018.

JULIANI, S. F.; SANTOS, L. M. F. Relações entre formação inicial de professores de ciências e projetos de extensão em educação ambiental. In: ENCONTRO NACIONAL DE PESQUISA EM EDUCAÇÃO EM CIÊNCIASS, 10, 2015, Águas de Lindóia. Anais... Águas de Lindóia: Abrapec, 2015. p. 1-8.

LAYRARGUES, P. P.; LIMA, G. F.C. As Macrotendências Político-Pedagógicas da Educação Ambiental Brasileira. Ambiente \& Sociedade, São Paulo, v. 17, n. 1, p. 23-38, 2014.

LEITE, R. F.; RODRIGUES, M. A. Educação ambiental na formação profissional de professores de Química. In: ENCONTRO NACIONAL DE PESQUISA EM EDUCAÇÃO EM CIÊNCIAS, 8, 2011, Campinas. Anais... Campinas: Abrapec, 2011. p.1-10.

LOPES, A. C.; MACEDO, E. Teorias de Currículo. São Paulo: Cortez, 2011.

LOPES, T. M.; ZANCUL, M. C. S. A Temática Ambiental nos cursos de Licenciatura em Ciências Biológicas da Universidade Federal de São Carlos. In: ENCONTRO NACIONAL DE PESQUISA EM EDUCAÇÃO EM CIÊNCIAS, 8, 2011, Campinas. Anais... Campinas: Abrapec, 2011. p.1-12.

LOBO-SANTOS, V.; AIRES, J. L. O Estado da Arte das Pesquisas em Formação de Professores em Educação Ambiental: uma análise do perfil das publicações do Encontro de Pesquisa em Educação Ambiental - EPEA (2005-2015). In: ENCONTRO NACIONAL DE PESQUISA EM EDUCAÇÃO EM CIÊNCIAS, 11, 2017, Florianópolis. Anais... Florianópolis: Abrapec, 2017. p.1-11.

LOUREIRO, C. F. B. Premissas teóricas para uma educação ambiental transformadora. Ambiente e Educação, Rio Grande, v. 8, n. 1, p. 37-54, 2003.

LOUREIRO, C. F. B. Complexidade e Dialética: contribuições à práxis política e emancipatória em educação ambiental. Educação \& Sociedade, Campinas, v. 27, n. 94, p. 131-152, 2006.

LOUREIRO, C. F. B.; FRANCO, J. B. Aspectos teóricos e metodológicos do Círculo de Cultura: uma possibilidade pedagógica e dialógica. In: LOUREIRO, C. F. B.; TORRES, J. R. (org.). Educação Ambiental: dialogando com Paulo Freire. São Paulo, SP: Cortez, 2014. p.155-180.

MARTINS, G. A.; SOUZA, P. O.; PAULOS, G. S.; BRANDO, F. R.; BONZANINI, T. K. Indicadores de interdisciplinaridade em um grupo de estudos: uma reflexão ao ensino de temas ambientais na formação inicial de professores. In: ENCONTRO NACIONAL DE PESQUISA 
DOI: https://doi.org/10.33238/ReBECEM.2020.v.4.n.2.24146

EM EDUCAÇÃO EM CIÊNCIAS, 11, 2017, Florianópolis. Anais... Florianópolis: Abrapec, 2017. p. 1-11.

MEC. Diretrizes Curriculares Nacionais Gerais da Educação Básica. Brasília: Secretaria da Educação Básica, 2013.

MEJÍA, A. M. et al. A Educação Ambiental na formação inicial de professores de Ciências: Um estudo de caso na Universidad del Valle, Colombia. In: ENCONTRO NACIONAL DE PESQUISA EM EDUCAÇÃO EM CIÊNCIAS, 9, 2013. Águas de Lindóia. Anais... Águas de Lindóia: Abrapec, 2013. p.1-8.

MORAES, R.; GALIAZZI, M. C. Análise Textual Discursiva. 3. ed. Ijuí: Editora Unijuí, 2016.

MOTA, J. C.; COUSIN, C. S.; KITZMANN, D. I. S. A Educação Ambiental Estética e as Relações de Pertencimento no Processo de Ambientalização Curricular. Revista Pedagógica, Chapecó, v. 20, n. 45, p. 207-226, 2018.

PERLINGEIRO, R. V. et al. A Educação Ambiental na formação inicial em um curso de Ciências Biológicas: visões dos licenciandos. In: ENCONTRO NACIONAL DE PESQUISA EM EDUCAÇÃ̃O EM CIÊNCIAS, 9, 2013, Águas de Lindóia. Anais... Águas de Lindóia: Abrapec, 2013. p. 1-8.

RIBEIRO, T. V.; GENOVESE, L. G. R.; COLHERINHAS, G. O Ensino por Pesquisa no Ensino Médio: Discussão de Questões CTSA em uma Alfabetização Científico-Tecnológica. In: ENCONTRO NACIONAL DE PESQUISA EM EDUCAÇÃO EM CIÊNCIAS, 8, 2011, Campinas. Anais... Campinas: Abrapec, 2011. p. 1-14.

RIOS-RAMIARINA, N. T. Educação Ambiental e Direitos Humanos na Formação Inicial de Professores de Ciências Biológicas. In: ENCONTRO NACIONAL DE PESQUISA EM EDUCAÇÃO EM CIÊNCIAS, 11, 2017, Florianópolis. Anais... Florianópolis: Abrapec, 2017. p. 1-9.

SAUVÉ, L. Uma cartografia das correntes em educação ambiental. In: SATO, M.;

CARVALHO, I. C. M. (org.). Educação Ambiental: pesquisas e desafios. Porto Alegre: Artmed, 2005. p. 17-45.

SILVA, D. F.; PATACA. E. M. As concepções das práticas de pesquisa e de ensino na formação de professores reflexivos em Geociências e Educação Ambiental. In: ENCONTRO NACIONAL DE PESQUISA EM EDUCAÇÃO EM CIÊNCIAS, 9, 2013, Águas de Lindóia. Anais... Águas de Lindóia: Abrapec, 2013. p.1-8.

SILVA, L. F. S.; CARVALHO, L. M. A Temática Ambiental e o Ensino de Física: As Diferentes Compreensões dos Professores de Física em Formação Inicial. In: ENCONTRO NACIONAL DE PESQUISA EM EDUCAÇÃO EM CIÊNCIAS, 8, 2009, Florianópolis. Anais... Florianópolis: Abrapec, 2009. p.1-13.

SILVA, R. C.; GALLO, Â. C.; OLIVEIRA, G. F. Educação socioambiental na Licenciatura em Ciências Biológicas da UFRPE. In: ENCONTRO NACIONAL DE PESQUISA EM EDUCAÇÃO EM CIÊNCIAS, 8, 2011, Campinas. Anais... Campinas: Abrapec, 2011. p.1-8.

SILVA, T. N.; FARIAS, C. R. O. Políticas curriculares e ambientalização da formação inicial de professores de Química de uma Universidade Pública de Pernambuco. In: ENCONTRO NACIONAL DE PESQUISA EM EDUCAÇÃO EM CIÊNCIAS, 10, 2015, Águas de Lindóia. Anais... Águas de Lindóia: Abrapec, 2015. p. 1-8. 
DOI: https://doi.org/10.33238/ReBECEM.2020.v.4.n.2.24146

SOUZA, M. L. Histórias de Professores de Química em Rodas de Formação em Rede: colcha de retalhos tecida em partilhas (d)e narrativas. Íjui: Editora Uníjui, 2011.

STALLONY, G.; ROCHA, D. C.; PEREIRA, M. G.; BARBOSA, A. T. Ambientalização Curricular no Curso de Ciências Biológicas Numa Universidade Pública: Primeiros Resultados. In: ENCONTRO NACIONAL DE PESQUISA EM EDUCAÇÃO EM CIÊNCIAS, 8, 2011, Campinas. Anais... Campinas: Abrapec, 2011. p.1-14.

TAVOLARO, S. B. F. Ação Comunicativa. In: JÚNIOR L. A. F. (org.). Encontros e Caminhos: formação de educadores ambientais e coletivos educadores. Brasília: MMA, Diretoria de Educação Ambiental, 2005. p. 17-25.

TORRES, J. R.; FERRARI, N.; MAESTRELLI, S. R. P. Educação Ambiental críticotransformadora no contexto escolar: teoria e prática freireana. In: LOUREIRO, C. F. B.; TORRES, J. R. (org.). Educação Ambiental: dialogando com Paulo Freire. São Paulo: Cortez, 2014. p. 13-80.

TOZONI-REIS, M. F. C. Contribuições para uma pedagogia crítica na educação ambiental: reflexões teóricas. In: LOUREIRO, C. F. B. (org). A questão ambiental no pensamento crítico: natureza, trabalho e educação. Rio de Janiero: Quartet, 2007. p. 177-221.

VELOSO, N. D.; DAL-FARRA, R. A.; VELOSO, M. S. S. O. Concepções ambientais e interdisciplinares de Licenciandos em Matemática em Boa Vista-RR. In: ENCONTRO NACIONAL DE PESQUISA EM EDUCAÇÃO EM CIÊNCIAS, 11, 2017, Florianópolis. Anais... Florianópolis: Abrapec, 2017. p.1-8.

VIVEIRO, A. A.; CAMPOS, L. M. L. Modalidades Didáticas e a Inserção da Temática Ambiental em um Curso de Formação de Professores de Ciências. In: ENCONTRO NACIONAL DE PESQUISA EM EDUCAÇÃO EM CIÊNCIAS, 6, 2007, Florianópolis. Anais... Florianópolis: Abrapec, 2007. p.1-12.

VIZEU, F.; MENEGHETTI, F. K.; SEIFERT, R. E. Por uma crítica ao desenvolvimento sustentável. Cadernos EBAPE.BR, Rio de Janeiro, v. 10, n. 3, p. 569-583, 2012.

Recebido em: 28 de fevereiro de 2020

Aceito em: 20 de julho de 2020 